\title{
GAYA WACANA MEDIA DALAM KONTRUKSI MEDIA TENTANG PEMBERITAAN ELEKTABILITAS PRESIDEN
}

\author{
Achmad Naufal Irsyadi
}

naufalirsyadiachmad@gmail.com

Fakultas Ilmu Budaya Universitas Jember

Jember, Jawa Timur, Indonesia

\begin{abstract}
This article discusses the news relating to the electability of Indonesian President Joko Widodo in the 2019 Presidential Election published in online media. It aims to reveal the style of discourse in media construction about electability reporting on Joko Widodo in MetrotvNews.com. It employs Critical Discourse Analysis of Fairclough which involves analysis of text dimensions and discourse practice. For uncovering and discovering the style of media discourse, the stylistical theory of Ali Imron Al-Mufruf is used. The source of data is the online media in the form of news that reports about Joko Widodo electability in 2019 presidential election. Data analysis is done by referential method to other related reports at MetrotvNews.com. The result shows the discourse style of parallelism used by metrotvnews.com in reporting the electability of Indonesian President Joko Widodo with different time and word but showing a similarity in discourse.
\end{abstract}

Keywords: Electability, Fairclough's Critical Discourse Analysis, Media Construction, Media Discourse Style

\section{PENDAHULUAN}

Istilah politik merupakan istilah yang tidak asing di kalangan masyarakat, khususnya Indonesia. Politik dapat menjadi salah satu potret kesibukan suatu kelompok dalam suatu masyarakat. Frankel (2006:38) mengatakan bahwa politik adalah tentang bagaimana segala sesuatu dalam pemerintahan, lembaga, tempat kerja, dan organisasi professional diselesaikan. Segala sesuatu tersebut dilakukan tidak hanya oleh satu lembaga ataupun badan organisasi saja, melainkan oleh kerjasama dengan beberapa lembaga ataupun badan organisasi terkait yang sudah membuat suatu perjanjian untuk mensukseskan sebuah proyek kerja. Dengan demikian, Frankel juga mengatakan bahwa hubungan dan kerjasama tersebut merupakan bisnis dalam politik yang melahirkan timbal balik dan pengaruh antar mitra politik.

Di Indonesia, potret hubungan dan mitra perpolitikan cenderung memunculkan anggapan yang kurang positif di kalangan masyarakat. Beberapa partai politik yang merupakan sebuah organisasi yang dibangun bersama atas dasar suka-rela dan bersama demi kepentingan partai, masyarakat, bangsa dan Negara, mulai menunjukkan secara jelas mitra politiknya. Hal demikian dapat memperjelas persepsi masyarakat tentang alur dan jalannya perpolitikan di Indonesia oleh sejumlah partai politik. Kejelasan persepsi dan pemahaman masyarakat terhadap roda perpolitikan di Indonesia dapat juga disebabkan oleh faktor luar, yaitu peranan media massa dan beberapa tokoh penting nusantara dalam menarasikan situasi dan kabar perpolitikan di Indonesia.

Media massa merupakan alat yang digunakan sebagai penyampai pesan dan informasi dari sumber kepada khalayak yang dapat berupa surat kabar, film, radio, TV, dan sebagainya (Fadli, 2017:108). Peranan media massa begitu ragam dan sangat penting bagi beberapa kelompok masyarakat, khususnya kelompok masyarakat yang bergerak dalam 
bidang politik. Secara garis besar, bagi kebanyakan partai politik, media massa dapat dijadikan sebuah media untuk menyebarkan informasi tentang partainya dan mitra partainya, sehingga pemberitaan diarahkan pada bagaimana partai dan mitra partainya dapat diberitakan dengan sebaik mungkin untuk memicu munculnya persepsi baik di kalangan masyarakat. Dengan demikian, media massa tidak hanya berdiri sebagai media hiburan semata, akan tetapi juga sebagai media penyampai informasi yang akurat dan kredibel.

Pada tahun 2019, bangsa Indonesia menghadapi Pemilihan Presiden (Pilpres) yang dilaksanakan setiap 5 tahun sekali. Akhir-akhir ini, beberapa media massa memberitakan hal-hal yang berkaitan dengan Pilpres 2019 tersebut dengan berita yang luas kajiannya. Elektabilitas presiden Joko Widodo menjadi Trending pemberitaan di berbagai media. Tak banyak yang menilai bahwa Joko Widodo mendapatkan banyak dukungan untuk maju dan bahkan terpilih dalam Pilpres 2019 dikarenakan elektabilitasnya yang baik. Akan tetapi, di satu sisi, isu-isu negatif mengenai politik ras mulai muncul. Sebagian mengatakan bahwa isu tersebut dimunculkan untuk memobilisasi masyarakat agar memilih presiden dari sudut pandang agama dan kelompok etnisnya.

Artikel ini berusaha untuk membahas pemberitaan elektabilitas Joko Widodo di media massa Online Metrotvnews.com. Penelitian terhadap metrotv sebagai media massa sudah dikaji oleh beberapa penelitian ilmiah. Pada tahun 2013, Oji Kurniadi pada tahun 2013 mulai mengkaji metrotv dalam konteks budaya jurnalistiknya. Penelitiannya menemukan setidaknya enam simpulan tentang budaya jurnalistik metrotv, antara lain: 1) metrotv menjadi Top of Mind bagi pencari berita; 2) kuatnya kepentingan pemilik dalam mewarnai isi berita terutama yang berkaitan dengan suksesi menuju RI-1 pada tahun 2014; 3) berita kekerasan masih mendominasi pemberitaan dalam televisi; 4) komitemennya untuk mengurangi tayangantayangan tersebut dan lebih memilih untuk memberikan solusi tentang suatu perkara dan peristiwa; 5) banyaknya pelanggaran etika dalam pemberitaan di metrotv menunjukkan wawasan internal belum dilakukan secara maksimal; dan 6) cameraperson merupakan filter pertama dalam menseleksi gambar yang patut dan layak ditayangkan.

Penelitian selanjutnya dilakukan oleh Margynata Kurnia Putra dkk. pada tahun 2017 tentang perpektif TvOne dan Metrotv dalam memandang dan meninjau kebijakan pemerintahan Indonesia. Dalam hasil pengamatannya, penelitian tersebut menemukan bahwa antara TvOne dan Metrotv memiliki sudut pandang pemberitaan yang berbeda yang dapat diketahui melalui gerak tubuh, Setting, dan pola komunikasi para tamu undangan ketika berkomunikasi dengan pembawa acara pada saat itu. Selanjutnya, penelitian tersebut juga menemukan adanya sikap koperatif dan akomodatif terhadap pemerintahan Joko Widodo.

Kedua penelitian di atas setidaknya dapat memberikan gambaran tentang analisis kritis yang berkaitan dengan Positioning Act oleh media massa dalam pemberitaannya. Namun, penelitian ini akan berfokus pada pemberitaan elektabilitas Presiden RI Joko Widodo dan bagaimana media massa Metrotvnews.com memberitakan pemberitaan tersebut dalam sudut pandang Stilistika. Dengan bahasan tersebut, diharapkan dapat menghasilkan sebuah simpulan dinamis tentang gaya (Stilistika) wacana yang dilakukan oleh media massa. Kajian dalam artikel ini akan menggunakan kajian Analisis Wacana Kritis model Norman Fairclough tentang Teks, Praktik Diskursif, dan Praksis Sosial. Namun, dikarenakan tujuan utama penelitian ini adalah menemukan gaya wacana, maka artikel ini hanya akan melibatkan teks dan praktik diskursif saja.

\section{METODE}

Artikel ini menggunakan pendekatan bahasa untuk meninjau suatu pemberitaan dalam media massa Online tentang elektabilitas pemerintahan Joko Widodo dalam kaitannya dengan Pilpres 2019. Sumber data dalam artikel ini berupa MetrotvNews Online. Data yang digunakan berupa berita tentang Elektabilitas Joko Widodo dalam kaitannya dengan Pilpres 2019 yang dilansir pada 20 Desember 2017. Data dikumpulkan dengan menggunakan metode simak. Sedangkan, analisis data dilakukan dengan metode referensial dengan melihat berbagai pemberitaan terkait di MetrotvNews.com. 
Teori yang digunakan dalam artikel ini adalah Analisis Wacana Kritis Norman Fairclough. Norman Fairclough mengemukakan bahwa wacana merupakan sebuah praktik sosial dan membagi analisis wacana ke dalam tiga dimensi yaitu Text, Discourse Practice, dan Sosial Practice (Haryatmoko, 2016:23; Badara, 2012:26). Akan tetapi, artikel ini hanya akan melibatkan dua dimensi wacana saja, yaitu dimensi teks dan Discourse Practice. Hal ini dilakukan untuk memfokuskan dan mengkontrol substansi analisis, yaitu mengungkap gaya wacana media.

Secara umum, Text berhubungan dengan linguistik, misalnya dengan melihat kosakata, semantik, dan tata kalimat, juga koherensi dan kohesivitas, serta bagaimana antarsatuan tersebut membentuk suatu pengetian (Munfarida, 2014:9). Dalam artikel ini, kajian tentang Text akan membahas tentang unsur-unsur kebahasan yang terdapat di dalam pemberitaan elektabilitas Presiden RI Joko Widodo. Sehingga, untuk memperkuat temuan linguistik, peneliti akan menggunakan Stilistika.

Sementara itu, Discourse Practice (DP) merupakan dimensi yang berhubungan dengan proses produksi dan konsumsi teks (Munfarida, 2014:9); misalnya, pola kerja, bagan kerja, dan rutinitas saat menghasilkan berita. Dalam hal ini, DP akan membahas tentang proses produksi teks yang menyangkut identitas media massa metrotvnews.com.

Untuk mengetahui gaya wacana di metrotvnews.com terkait pemberitaan elektabilitas Presiden RI Joko Widodo, maka diperlukan analisis stilistika. Stilistika (secara sederhana) adalah ilmu tentang gaya bahasa. Gaya adalah wujud penggunaan bahasa pengarang yang bertujuan untuk menyatakan gambaran, gagasan, dan pendapat, sehingga gaya bahasa tersebut menghasilkan efek tertentu bagi penanggapnya. Pengkajian gaya bahasa sebagai wujud penggunaan bahasa pengarang yang menjadi ciri khas pribadi pengarang merupakan salah satu kecenderungan dari Stilistika (Munir, 2013:3).

Al-Ma'ruf (2010:18) menekankan bahwa gaya bahasa yang melekat dalam diri dan ideologi seorang pengarang adalah sebagai aroma dalam sebuah makanan yang berfungsi untuk meningkatkan selera dan rasa. Gaya bahasa juga dapat digunakan untuk menentukan dan menemukan karakteristik sebuah wacana yang ada (Sulistyono, 2016:74). Dalam konsep gaya bahasa dalam suatu teks sastra.

Al-Ma'ruf memberikan beberapa klasifikasi fungsi gaya bahasa, yang diantaranya adalah: 1) gaya bahasa dapat meningkatkan minat pembaca pendengar untuk mengikuti apa yang disampaikan seorang pengarang/pembicara; 2) gaya bahasa dapat membuat pembaca/pendengar semakin yakin dan percaya terhadap apa yang disampaikan oleh pengarang/pembicara; 3) gaya bahasa dapat membawa pembaca/pendengar hanyut dalam suasana hati tertentu setelah menangkap apa yang disampaikan oleh seorang pengarang/pembicara; dan 4) gaya bahasa dapat membuat pembaca terkesan oleh gagasan yang disampaikan oleh pengarang/pembicara.

Terdapat dua kecenderungan dalam model kerja Stilistika Al-Ma'ruf, yakni Stilistika Deskriptif dan Stilistika Genetik. Model Stilistika Al-Ma'ruf berlandaskan pada formulasi dari setidaknya tiga pakar, yakni Abrams (1981), Keraf (1991), dan Pradopo (2004), sehingga lahirlah sebuah formula yang menjadi model Stilistika Al-Ma'ruf, yakni Diksi (Unsur Leksikal), Kalimat (Unsur Sintaksis), Wacana (Unsur Wacana), Bahasa Figuratif, dan Citraan. Namun, dalam artikel ini, peneliti hanya akan melibatkan unsur stilistika wacana untuk mengetahui gaya wacana yang digunakan oleh metrotvnews tentang elektabilitas Presiden RI Joko Widodo.

\section{HASIL DAN PEMBAHASAN Dimensi Teks}

Analisis dimensi teks meliputi bentukbentuk tradisional analisis linguistik yang meliputi analisis kosakata, semantik, tata bahasa kalimat, unit-unit lebih kecil, sistem suara (fonologi) dan sistem tulisan. Berikut ini merupakan temuan Analisis Linguistik dari teks pemberitaan tentang Elektabilitas Joko Widodo dan Isu Politik Ras.

Tabel 1. Temuan data dimensi teks

\section{Temuan Data}

1 Populi Center menilai tingkat kepuasan masyarakat terhadap Presiden Joko Widodo berbanding lurus dengan elektabilitasnya 
2 ... tingkat elektabilitas tersebut dapat merosot jika Jokowi diserang dengan politik identitas menjelang Pemilihan Presiden (Pilpres) 2019.

3 ... ada peningkatan tingkat kepuasan terhadap Jokowi dalam tiga tahun pemerintahannya ini

4 Tingkat elektabilitas Jokowi pun kini masih yang tertinggi dibandingkan calon lain.

5 Jokowi diminta agar tak cepat puas soal elektabilitas yang tinggi.

6 Elektabilitas tak selalu berbanding lurus dengan tingkat keterpilihan

7 Menurut dia, munculnya gap antara tingkat kepuasan dan elektabilitas ini dipengaruhi oleh politik identitas.

8 "Karena ada identity politic, ini sebagai imbas dari politik internasional secara keseluruhan karena Donald Trump juga memainkan isu yamg sama identity politic dan itu yang harus diantisipasi di 2018-2019," ucap dia.

Berdasarkan tabel di atas, dapat ditemukan beberapa dominasi komponen Linguistik seperti Repetisi dan Perbandingan.

\section{Dimensi Wacana}

Praktik wacana meliputi cara-cara para pekerja media memproduksi teks. Proses produksi teks dalam prinsip wacana Fairclough berkaitan dengan pengalaman, pengetahuan, kebiasaan, lingkungan sosial, kondisi, keadaan, konteks, dan hal lainnya yang melekat pada pembuat teks/pencipta teks wacana (Saraswati dan Sartini, 2017:183). Jika ditarik ke ranah yang lebih luas, hal ini mempengaruhi anggota atau individu-individu yang berada di bawahnya, seperti wartawan.

Produksi teks sebagai wacana juga berkaitan dengan wartawan itu sendiri selaku pribadi; sifat jaringan kerja wartawan dengan sesama pekerja media lainnya; pola kerja media sebagai institusi, seperti cara meliput berita, menulis berita, sampai menjadi berita di dalam media. Dengan demikian, Fairclough (melalui Saraswati dan Sartini) mengemukakan bahwa analisis kewacananan berfungsi untuk mengetahui proses produksi, penyebaran, dan penggunaan teks.

Berdasarkan pemberitaan di MetroNews Online yang menjadi sasaran analisis dalam artikel ini, topic Politik Identitas Dinilai Bisa Menjegal Jokowi di Pilpres 2019 ditulis oleh Achmad Zulfikar Fazli pada Rabu,
20 Desember 2017 pukul 19:59 WIB di Jakarta dan diterbitkan secara Online. Sebagaimana dikutip dalam https://id.linkedin.com/, Achmad Zulfikar Fazli merupakan seorang Jurnalis dalam MetroTvnews.com. MetroTV adalah sebuah stasiun televisi swasta yang berkedudukan di Indonesia. MetroTV didirikan oleh PT Media Televisi Indonesia, resmi mengudara sejak 25 November 2000 di Jakarta. MetroTV dimiliki Media Group pimpinan Surya Paloh yang juga memiliki harian Media Indonesia dan Lampung Post. PT Media Televisi Indonesia merupakan anak perusahaan dari Media Group, suatu kelompok usaha media yang dipimpin oleh Surya Paloh, yang juga merupakan pemilik surat kabar Media Indonesia. PT Media Televisi Indonesia memperoleh izin penyiaran atas nama "MetroTV" pada tanggal 25 Oktober 1999_(Mabruri, 2013:13).

Mabruri menambahkan bahwa pada tanggal 25 November 2000, pertama kali MetroTV mengudara dalam bentuk siaran ujicoba di 7 kota. Pada awalnya, hanya bersiaran 12 jam sehari, namun sejak tanggal 1 April 2001, MetroTV mulai mengudara selama 24 jam, menjadikan MetroTV sebagai stasiun TV pertama di Indonesia yang duluan bersiaran 24 jam.

\section{Politik Identitas Dinilai Bisa Menjegal Jokowi di Pilpres 2019 (Tinjauan Analisis Linguistik)}

Teks adalah semua bentuk bahasa yang dapat meliputi ekspresi komunikasi, ucapan, music, gambar, efek suara, citra, dan tulisan dalam lembaran kertas (Eriyanto, 2001:9). Sebagai sebuah bentuk wacana, Fairclough (dalam Rizki, 2016:48) menyebutkan tiga fungsi teks sebagai sarana penyampai wacana, yaitu fungsi identitas sosial, fungsi relasional, dan fungsi ideasional. Dengan menganalisis teks secara kritis, kita akan menemukan sebuah representasi dari sebuah identitas sosial tentang bagaimana seseorang, peristiwa, kelompok sosial, dan sebuah situasi ditampilkan dalam sebuah teks. Tentunya, hal tersebut akan berakar pada identitas pembuat teks itu sendiri.

Dalam langkah pertama analisis teks, Fairclough memberikan rekomendasi tentang peninjauan terhadap unsur kebahasaan suatu teks. Aspek koherensi dan kohesi merupakan dua aspek yang penting dalam pembentukan 
wacana atau teks dari segi kebahasaannya, sehingga keutuhan sebuah teks bergantung pada tingkat koherensi dan kohesinya (Winarto.dkk, 2016:186). Koherensi adalah pertalian dari dua kalimat atau kata yang berbeda yang dapat dihubungkan, sehingga tampak koheren (Eriyanto, 2001:242). Sedangkan, kohesi adalah hubungan antarbagian dalam teks yang ditandai penggunaan unsur bahasa. Konsep kohesi pada dasarnya mengacu kepada hubungan bentuk, artinya unsur-unsur wacana (kata atau kalimat) yang digunakan untuk menyusun suatu wacana memiliki keterkaitan secara padu dan utuh (Mulyana, 2005: 26).

Berdasarkan tabel di atas, ditemukan bahwa terdapat dua macam fitur bahasa yang terkandung dalam teks pemberitaan tentang Elektabilitas Joko Widodo di MetroTv News. Fitur bahasa tersebut adalah repetisi dan perbandingan. Nurdin (dalam Kuspriyono, 2015:3) mengatakan bahwa repetisi adalah sebuah ungkapan gaya bahasa yang menyatakan maksud dan tujuannya dengan cara melakukan pengulangan frasa, kata, ataupun klausa pada kalimatnya. Tujuannya adalah untuk menegaskan kembali makna pada maksud dan tujuan dari kalimat.

Dalam pemberitaan Elektabilitas Joko Widodo, ditemukan beberapa cuplikan repetisi yang digunakan di dalamnya, yaitu Elektabilitas yang dinyatakan sebanyak 5 kali, dan Politik Rasial sebanyak 3 kali. Repetisi tersebut dapat memberikan beberapa tafsiran sebagaimana berikut ini:

1) Elektabilitas Joko Widodo berbanding lurus dengan tingkat kepuasaan masyarakat Indonesia terhadap rezim Joko Widodo;

2) Elektabilitas Joko Widodo terbukti dengan adanya peningkatan tingkat kepuasan terhadap Joko Widodo dalam tiga tahun pemerintahannya;

3) Tingkat elektabilitas Joko Widodo masih yang tertinggi dibandingkan calon lain;

4) Politik Rasial mulai muncul semenjak kemenangan Anis Baswedan-Sandiaga Uno dalam Pilkada DKI Jakarta tahun 2017;

5) Politik rasial menenggelamkan Basuki Thahja Purnama (Ahok) ke dalam kekalahan, meskipun Elektabilitasnya melebihi elektabilitas Anis BaswedanSandiaga Uno;

Berdasarkan uraian tafsiran repetisi tersebut, dapat dikatakan bahwa Basuki Thahja Purnama (Ahok) dan Joko Widodo (dalam pemberitaan ini) merupakan dua figur yang memiliki elektabilitas dan tingkat kepuasan yang tinggi yang (akan) dihadapkan pada isu politik rasial yang mewarnai perpolitikan di Indonesia. Berdasarkan teks berita tersebut, kekalahan Ahok disebabkan oleh politik rasial yang dimainkan oleh beberapa oknum politik. Oleh sebab itu, penulis berita mengatakan bahwa Joko Widodo diharap untuk tetap waspada terhadap elektabiltasnya, karena elektabilitas tidak selalu berbanding lurus dengan tingkat keterpilihan masyarakat.

Fitur kebahasaan yang lainnya adalah perbandingan. Dalam suatu perbandingan, sesuatu dibandingkan dengan sesuatu yang lainnya dengan berbagai sudut pandang sebagai pembandingnya. Perbandingan dapat dinyatakan secara eksplisit dan implisit, bergantung pada pengguna bahasa ataupun pembuat teks itu sendiri. Secara eksplisit, perbandingan dinyatakan dengan menggunakan piranti pembanding (kosakata pembanding), seperti daripada, ketimbang, dibandingkan, lebih baik dari, tidak seperti, dan lain sebagainya. Berdasarkan konteks pemberitaan Elektabilitas Joko Widodo, fakta tentang perbandingan dapat dilihat dalam kutipan di bawah ini:

1) Tingkat elektabilitas Jokowi pun kini masih yang tertinggi dibandingkan calon lain.

Perbandingan dengan menggunakan kata "dibandingkan" merupakan sebuah cara membandingkan dan menganggap hal yang dijadikan objek perbandingan tidak sebagus subjek (apa yang dibandingkan) (Masruchin, 2017:10). Dalam kasus ini, tingkat elektabilitas Jokowi merupakan subjek perbandingan yang memiliki sifat melebihi (tertinggi) daripada calon lainnya sebagai objek yang dibandingkan, sehingga dapat dikatakan bahwa tidak ada yang mampu menandingi elektabilitas Jokowi. Hal itu diperkuat dengan adanya unsur tingkat perbandingan Superlatif (dalam Bahasa Inggris: Superlative Degree) berupa kata "tertinggi". 


\section{Gaya Wacana Elektabilitas Joko Widodo di Metrotvnews.com (Konstruksi Identitas Media dan Stilistika Media)}

Fairclough menganggap analisis terhadap teks saja seperti yang banyak dikembangkan oleh ahli linguistik tidak cukup, karena tidak bisa mengungkap lebih jauh dan mendalam kondisi sosio-kultural yang melatarbelakangi munculnya teks. Begitu juga sebaliknya, pandangan ini juga sekaligus mengkritik para pengikut post-strukturalis yang lebih menekankan pada aspek sosiokultural dari munculnya teks tanpa menyediakan metodologi yang memadai bagi analisis teks yang pada dasarnya merupakan representasi dan artikulasi dari pemikiran, kepentingan, dan ideologi yang dilekatkan pada teks.

Elektabilitas Joko Widodo, Isu Politik Rasial, dan Pilpres 2019 dapat menjadi sebuah penggalan teks/wacana yang ditulis berbeda, namun memiliki keterkaitan secara pragmatis dan diskursif. Dalam pemberitaan tentang Elektabilitas Joko Widodo pada media Online Metrotv News dengan Headline "Politik Identitas Dinilai Bisa Menjegal Jokowi di Pilpres 2019", merupakan pemberitaan yang tidak lepas dari peranan media yang meliputi posisi media dalam dunia politik. Elektabilitas Joko Widodo dinyatakan secara jelas dengan sudut pandang yang baik dibandingkan dengan pemberitaan/pernyataan tentang politik rasial yang dimunculkan dalam teks berita tersebut.

Sebab itu, figur Joko Widodo mendapatkan Imagery yang baik dalam berita yang dimuat oleh media Online tersebut. Sedangkan, elit/figur politik lainnya yang juga menjabat sebagai Gubernur terpilih DKI Jakarta: Anies Baswedan dan Sandiaga Uno secara terang-terangan dan eksplisit disebutkan sebagai wakil rakyat yang terpilih bukan karena elektabilitasnya, melainkan karena politik rasial yang disebarkan untuk memobilisasi masyarakat guna memilih mereka menjadi Gubernur DKI Jakarta.

Gaya wacana paralelisme yang digunakan dalam memberitakan elektabilitas Presiden RI Joko Widodo mewarnai pemberitaan dalam Metrotvnews.com. gaya wacana paralelisme tersebut menunjukkan adanya kohesi dan koherensi dalam masingmasing teks/berita di metrotvnews.com yang memberitakan elektabilitas Presiden RI Joko
Widodo. Dalam hal ini, Subahnan (2016:87) menilai penggunaan gaya wacana paralelisme dalam wacana kampanye pemilu presiden meliputi kata, frase, kelompok kata, dan kalimat yang pada hakikatnya menduduki fungsi yang sama dalam bentuk gramatika yang sama.

Gaya wacana paralelisme dalam pemberitaan ini secara tidak langsung menjalankan prinsip wacana Fairclough bahwa bahasa merupakan sebuah praktik kekuasaan (Saraswati dan Sartini, 2017:182). Meskipun secara gramatika bahasa kata yang digunakan berbeda, akan tetapi memiliki maksud yang sama. Beberapa cuplikan berita terkait elektabilitas Presiden RI Joko Widodo dapat dilihat di gambar berikut:

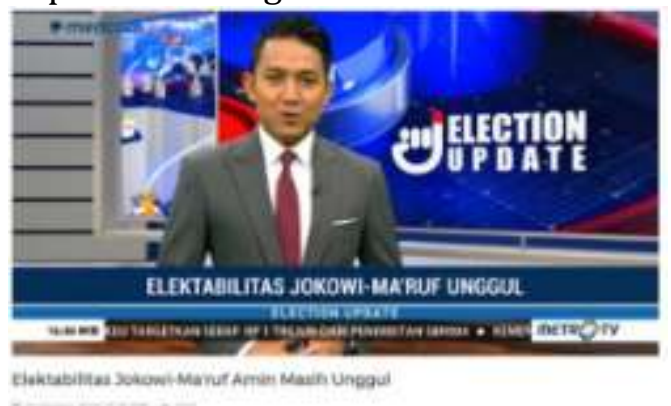

Gambar 1. Pemberitaan elektabiltas Presiden RI Joko Widodo pada 21 Agustus 2018

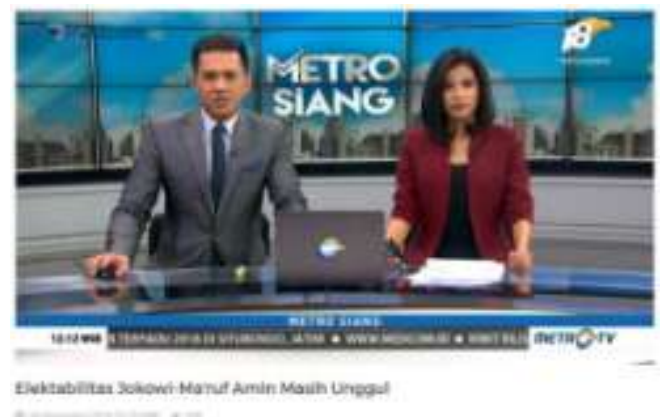

Gambar 2. Pemberitaan elektabilitas Presiden RI Joko Widodo pada 28 November 2018

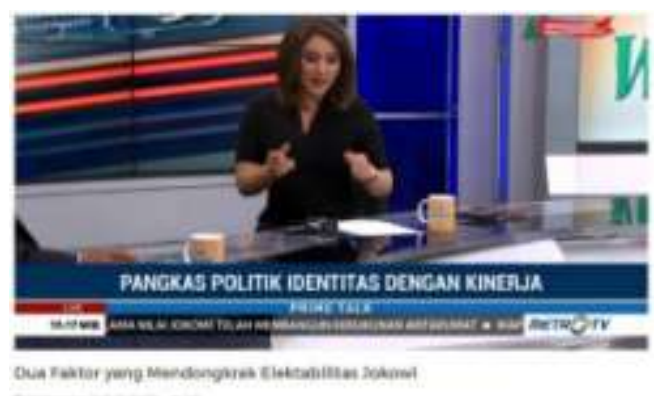

Gambar 3. Pemberitaan elektabilitas Presiden RI Joko Widodo pada 20 Desember 2018

Kohesi dan koherensi pemberitaan elektabilitas Presiden RI Joko Widodo dibentuk oleh mekanisme penggunaan 
repetisi sebagai gaya wacana. Dengan repetisi semacam itu, maka pendapat Al-Ma'ruf tentang fungsi bahasa melalui gaya wacana dapat dibenarkan.

Dengan demikian, repetisi wacana dilakukan dengan cara mengulang unsur kalimat yang meliputi kata untuk memberikan kesan bahwa apa yang diulang merupakan sesuatu yang penting dan benar (Sugiyati, 2011:7). Permainan wacana melalui repetisi tersebut dapat meningkatkan minat pembaca/pendengar berita untuk menyetujui apa yang disampaikan media, membuat pembaca/pendengar berita semakin yakin dan percaya terhadap apa yang disampaikan dalam media, dapat membawa pembaca/pendengar berita hanyut dalam keyakinan tentang pilihannya setelah menangkap apa yang disampaikan oleh media; dan dapat membuat pembaca terkesan oleh gagasan yang disampaikan oleh media dikarenakan sarana stilistika wacana lainnya, seperti fakta yang disertai gambar dan pendapat tokoh.

\section{KESIMPULAN}

Media berperan penting dalam memobilisasi dan mengkonstruksi sebuah ideologi publik dengan pemberitaan dan gaya redaksinya yang khas dan persuasif. Keberadaan media tidak bisa dipisahkan dengan kondisi perpolitikan dari masa ke masa, hingga pada akhirnya banyak dari kalangan elit politik yang memegang kendali atas sebuah media, dan bahkan beberapa media. Sebagai sebuah mahakarya, media dibangun atas dasar institusional, koordinatif, ideologis, serta visioner. Tentunya, keempat elemen tersebut mempengaruhi pemberitaan dan gaya pemberitaan suatu media tentang sesuatu.

Dalam kasus ini, penulis melihat adanya hubungan terikat antara teks pemberitaan Elektabilitas Presiden RI Joko Widodo dalam Metrotv News Online dengan bagan konstruksinya, yaitu Metro Tv yang diakomodir oleh pimpinan Metro Tv sebagai salah satu elit politik yang berada dalam barisan pendukung Joko Widodo. Selain itu, ditinjau dari sudut pandang stilistika wacana media, pemberitaan tentang elektabilitas Joko Widodo diberikan dengan gaya wacana paralelisme untuk menciptakan kohesi dan koherensi berita dalam mendapatkan kepercayaan publik.

\section{DAFTAR PUSTAKA}

Al-Ma'ruf, A.I. 2010. Kajian Stilistika: Perspektif Kritik Holistik. Surakarta: UNS Press.

Badara, A. (2012). Analisis Wacana: Teori, Metode, dan Penerapannya pada Wacana Media. Jakarta: Kencana Prenada Media Group.

Eriyanto. (2001). Analisis Wacana: Pengantar Analisis Teks Media. Yogyakarta: LKiS.

Fadli, A.M.D. (2017). Buku Ajar Sistem Politik Indonesia. Yogyakarta: Deepublish.

Frankel, L.P. (2006). Nice Girls Don't Get The Corner Office: 101 Kesalahan Perempuan Yang Menghambar Karier. Jakarta: Gramedia Pustaka Utama.

Haryatmoko. (2016). Critical Discourse Analysis (Analisis Wacana Kritis): Landasan Teori, Metodologi dan Penerapan). Jakarta: PR RajaGrafindo Persada.

Kurniadi, O. (2013). Budaya Jurnalistik di Metro TV. Jurnal Kajian Komunikasi, 1(2): 133-140.

Kuspriyono, T. (2015). Penggunaan Gaya Bahasa pada Iklan PT. L’Oreal Indonesia (Studi Kasus PT. L'Oreal Indonesia. Jurnal Komunikasi, VI(1): 1-9.

Mabruri, A. (2013). Manajemen Produksi Program Acara TV: Format Acara Non-Drama. News \& Sport. Jakarta: Grasindo. 
Masruchin, U.N. 2017. Buku Pintar Majas, Pantun, dan Puisi. Depok: HUTA PUBLISHER.

Munfarida, E. (2014). Analisis Wacana Kritis dalam Perspektif Norman Fairclough. Komunika, 8(1): 1-19.

Munir, S. 2013. Diksi dan Majas dalam Kumpulan Puisi Nyanyian dalam Kelam Karya Sutikno W.S: Kajian Stilistika. Jurnal Sastra Indonesia, 2(1): 1-10.

Mulyana. (2005). Kajian Wacana.Yogyakarta: Tiara Wacana.

Putra, M.K et al. (2017). News Content Perspective of TV One and Metro TV in Seeing Indonesia Government Policy. Global Media Journal, 15(29:87): 1-5.

Rizki, J.W.S. (2016). Kepemilikan Media dan Ideologi Pemberitaan. Yogyakarta: Deepublish.

Saraswati, A., Sartini, N.W. (2017). Wacana Perlawanan Persebaya 1927 terhadap PSSI: Analisis Wacana Kritis Norman Fairclough. Mozaik Humaniora, 17(2): 181-191.

Subahnan. (2016). Pendayagunaan Gaya Bahasa dalam Wacana Kampanye. WACANA, 1(1): 82-94.

Sugiyati, M.S. (2011). Kajian Stilistika Wacana Cerpen di Kebun Binatang Karya Sutarji C.B. BISA, 611.

Sulistyono, Y. (2016). Struktur dan Fungsi Eufemisme dalam Rubrik Obituari Harian Kompas. Leksema, 1(2): 73-80.

Winarto, Y.T et al. (2016). Karya Tulis Ilmiah Sosial: Menyiapkan, Menulis, dan Mencermatinya. Jakarta: Yayasan Pustaka Obor Indonesia. 